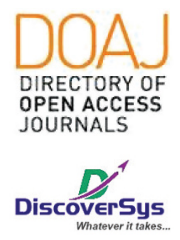

Published by DiscoverSys

\section{Karakteristik kanker kulit di Rumah Sakit Umum Pusat Sanglah Denpasar tahun 2015-2018}

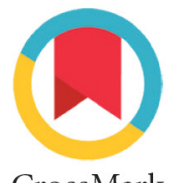

CrossMark

\begin{abstract}
Made Wardhana ${ }^{1 *}$, I Gusti Nyoman Darmaputra', I Gde Nengah Adhilaksman', Nyoman Yoga Maya Pramita ${ }^{2}$, Ricky Fernando Maharis ${ }^{2}$, Made Dwi Puspawati ${ }^{1}$, I Gusti Ayu Agung Dwi Karmila', I Gusti Agung Ayu Praharsini', I Gusti Ayu Agung Elis Indira', Nyoman Suryawati'
\end{abstract}

\title{
ABSTRAK
}

Latar belakang: Prevalesi kanker kulit semakin meningkat di seluruh dunia. Walaupun insiden tertinggi pada kelompok berkulit putih, namun mengetahui epidemiologi dan tren penyakit dari kanker kulit diperlukan agar dapat menentukan pencegahan dan penanganan yang tepat.

Tujuan: Untuk mengetahui karakteristik kanker kulit pada pasien yang telah dilakukan skin flap di Departemen Dermatologi dan Venereologi RSUP Sanglah.

Metode: Penelitian ini merupakan studi deskriptif retrospektif dari catatan medis semua penderita kanker kulit yang memperoleh tindakan skin flap sejak Januari 2015 sampai dengan Desember 2019. Sampel diambil melalui total sampling. Karakteristik yang tercatat meliputi jenis kanker, jenis kelamin, umur, tipe kulit, pekerjaan, dan jenis flap yang dilakukan. Data yang terkumpul dianalisis secara deskriptif dengan program SPSS Ver21.

Hasil: Terdapat 41 pasien kanker kulit yang memperoleh tindakan skin flap, terdiri dari 43,9\% ( $n=16) B C C, 54,6 \%(n=10)$ melanoma, $21,9 \%(n=9)$ SCC, 9,8\% ( $n=4)$ jenis kanker lain. Jenis flap yang umum digunakan yaitu simple advancement. Lokasi kanker paling umum ditemukan pada wajah dan kejadian kanker paling tinggi terjadi pada usia $\geq 50$ tahun dan bekerja di luar ruangan. Simpulan: Kasus kanker tertinggi yaitu BCC dengan usia lebih dari 50 tahun dan bekerja di luar ruangan sebagai karakteristik paling umum pada semua kasus kanker.

Kata Kunci: kanker kulit, skin flap, faktor resiko, profil kanker kulit Site Pasal Ini: Wardhana, M., Darmaputra, I.G.N., Adhilaksman, I.G.N., Pramita, N.Y.M., Maharis, R.F., Puspawati, M.D., Karmila, I.G.A.A.D., Praharsini, I.G.A.A., Indira, I.G.A.A.E., Suryawati, N. 2019. Karakteristik kanker kulit di Rumah Sakit Umum Pusat Sanglah Denpasar tahun 2015-2018. Intisari Sains Medis 10 (1): 260-263. D0I: 10.1556/ism.v10i1.438

'Departemen Dermatologi dan Venerologi, Fakultas Kedokteran Universitas Udayana/Rumah Sakit Umum Pusat Sanglah, DenpasarBali

${ }^{2}$ Residen Dermatologi dan Venerologi, Departemen Dermatologi dan Venerologi, Fakultas Kedokteran Universitas Udayana

\section{*Korespondensi :}

Made Wardhana; Departemen Dermatologi dan Venerologi, Fakultas Kedokteran Universitas Udayana/Rumah Sakit Umum Pusat Sanglah, Denpasar-Bali wardhanamade@unud.ac.id

Diterima : 2019-03-13 Disetujui : 2019-03-28 Diterbitkan : 2019-04-01

\section{PENDAHULUAN}

Kanker terjadi akibat adanya kerusakan pada DNA dan tubuh tidak mampu memulihkan kerusakan tersebut. Kanker kulit tumbuh pada lapisan yang berbeda, umumnya pada epidermis sehingga mudah dieknali ${ }^{1}$ Angka kejadian kanker kulit melanoma dan non-melanoma meningkat di seluruh dunia. ${ }^{2}$ Kelompok ras Asia, kulit hitam, dan hispanik tergolong kelompok dengan kejadian kanker kulit yang rendah. ${ }^{3}$ Walaupun secara epidemiologi kanker kulit merupakan keganasan yang paling umum terjadi pada populasi kulit putih, namun mempelajari tren epidemiologi diperlukan untuk mencapai kontrol yang adekuat dan pencegahan awal terhadap kanker kulit. ${ }^{4}$

Kanker kulit secara umum diklasifikasikan menjadi dua kelompok yaitu melanoma skin cancer (MSC) dan non-melanoma skin cancer (NMSC). Kanker kulit non-melanoma merupakan kanker yang paling umum pada manusia, termasuk squamous cell carcinoma (SCC), basal cell carcinoma (BCC) dan jenis kanker kulit lainnya seperti keratoachantoma, bechet disease, dan granuloma piogenikum. ${ }^{5}$ Karsinoma sel basal merupakan tipe kanker kulit paling sering (75\% - 80\%) dan merupakan kanker paling sering dari seluruh kanker. Walaupun BCC lebih sering terjadi, SCC memiliki mortalitas yang lebih tinggi karena kejadian metastasis yang lebih tinggi. ${ }^{4,5}$ Melanoma merupakan keganasan yang umum terjadi di negaranegara barat, terutama pada populasi dengan kulit yang lebih terang. Melanoma merupakan kanker paling sering kelima yang didiagnosis di Amerika Serikat, dengan insiden 21,9 per 100.000 ribu pasien per tahun. Insiden yang rendah di populasi Asia dengan kejadian 0,2 - 0,5 kasus per 100.000 pasien per tahun. ${ }^{6,7}$ Lebih dari $60 \%$ kasus melanoma akan berkembang menjadi metastasis sistem saraf pusat dengan insiden 100.000 sampai 300.000 pasien per tahun dan menjadi penyebab etiologi tersering ketiga. ${ }^{8}$ Jenis kanker kulit yang paling banyak terjadi di Indonesia adalah BCC (65,5\%), SCC (23\%), melanoma maligna (7,9\%), 
dan jenis lainnya. ${ }^{9}$

Pemilihan terapi pada kasus kanker kulit harus disesuaikan berdasarkan tipe histologi lesi, ukuran, lokasi, dan usia pasien. Tidak ada terapi tunggal yang ideal untuk semua lesi. Tujuan utama dari terapi pada kanker kulit adalah pengangkatan tumor secara keseluruhan, menjaga fungsi, dan hasil kosmetik yang baik. ${ }^{1,4}$ Modalitas terapi saat ini untuk kanker kuliat pada wajah yaitu eksisi, elektrokauter, kuretase, krioterapi, dan radiasi, namun operasi eksisi dilaporkan sebagai pilihan modalitas terbaik kanker kulit sebagai terapi dan mencegah kekambuhan. ${ }^{10,11}$ Terdapat empat metode rekonstruksi antara lain second intention, penutupan luka operasi melalui primary intention, penanganan luka dengan tindakan flap, dan tindakan graft. Skin flap dikerjakan bila penutupan primer pada defek eksisi tidak dapat dikerjakan karena luka terlalu besar, banyak regangan atau hasilnya mungkin kurang baik bila dilakukan penutupan primer. Operasi rekonstruksi dari defek setelah operasi harus dilakukan secara selektif dan mempertimbangkan metode operasi, lokasi defek, ukuran, tipe tumor, kemungkinan untuk kambuh, usia pasien, kondisi kesehatan, aspek fungsional, dan aspek kosmetik. ${ }^{2,10,11}$

Saat ini penggunaan skin flap menjadi pilihan terapi setelah reseksi tumor. Random pattern flaps merupakan pemindahan kulit dengan ketebalan

Tabel 1. Karakteristik umum kanker kulit

\begin{tabular}{cccc} 
Melanoma & BCC & SCC & Lainnya \\
$n(\%)$ & $n(\%)$ & $n(\%)$ & $n(\%)^{*}$ \\
$10(24,4)$ & $18(43,9)$ & $9(21,9)$ & $4(9,8)$ \\
\hline
\end{tabular}

Jenis kelamin

$\begin{array}{rcccc}\text { Laki-laki } & 6(14,6) & 11(26,8) & 3(7,3) & 3(7,3) \\ \text { Perempuan } & 4(9,8) & 7(17,1) & 6(14,6) & 1(2,4)\end{array}$

Umur

$\begin{array}{ccccc}<50 \text { tahun } & 4(9,8) & 5(12,2) & 2(4,8) & - \\ \geq 50 \text { tahun } & 6(14,6) & 13(31,7) & 7(17,1) & 4(9,8)\end{array}$

Tipe kulit

$\begin{array}{rcccc}\text { I-II } & 4(9,8) & 3(7,3) & 5(12,2) & - \\ \text { II-IV } & 6(14,6) & 13(31,7) & 3(7,3) & 4(9,8) \\ \text { V-VI } & - & 2(4,8) & 1(2,4) & -\end{array}$

Pekerjaan

\begin{tabular}{rcccc} 
Luar ruangan & $8(19,5)$ & $12(29,3)$ & $7(17,1)$ & $3(7,3)$ \\
Dalam ruangan & $2(4,8)$ & $6(14,6)$ & $2(4,8)$ & $1(2,4)$ \\
& & & & \\
Wajah & $8(19,5)$ & $15(36,6)$ & $6(14,6)$ & $3(7,3)$ \\
Badan/punggung & $2(4,8)$ & $3(7,3)$ & $3(7,3)$ & $1(2,4)$ \\
Simple Advancement & $6(14,6)$ & $12(29,3)$ & $5(12,2)$ & $4(9,8)$ \\
Tranposition & $2(4,8)$ & $4(9,8)$ & $3(7,3)$ & - \\
Rotation & $2(4,8)$ & $2(4,8)$ & $1(2,4)$ & - \\
\hline
\end{tabular}

Lokasi

${ }^{\star}$ Keratoachantoma (3), Bechet (1) penuh dari bagian donor ke dalam defek sementara tetap memelihara pasokan darah melalui pleksus dermal-subdermal pembuluh darah, yang berasal dari pembuluh darah kutaneus secara langsung, fasiokutan, dan muskulokutan. Berdasarkan tipe pergerakannya, random pattern flaps dibagi menjadi 4 jenis flap, yakni advancement flaps, transposition flaps, rotation flaps, dan interpolation flaps. ${ }^{11-13}$ Tujuan penelitian ini adalah untuk mengetahui karakteristik kanker kulit pada pasien yang telah dilakukan skin flap di Departemen Dermatologi dan Venereologi RSUP Sanglah.

\section{METODE}

Penelitian ini merupakan sebuah studi deskriptif retrospektif terhadap penderita yang memperoleh tindakan skin flaps sejak Januari 2015 hingga Desember 2019 di Departemen Dermatologi dan Venereologi, RSUP Sanglah. Sampel dipilih melalui total sampling tanpa menggunakan kriteria inklusi dan eksklusi. Diagnosis kanker kulit dapat ditegakkan dari anamnesis, pemeriksaan klinis dengan melihat efloresensi kulit, pemeriksaan penunjang seperti dermoskopi, serta pemeriksaan histopatologi sebagai baku emas. Data sekunder dikumpulkan dari rekam medis penderita dan hasil pencatatan kemudian dikelompokkan berdasarkan jenis kanker kulit, kelompok umur, jenis kelamin, jenis kulit dan jenis skin flap. Data yang terkumpul akan diinput dan dianalisis sesuai dengan analisis deskriptif melalui program SPSS Ver21.

\section{HASIL}

Terdapat 41 pasien dengan kanker kulit yang mendapatkan tindakan bedah eksisi dan skin flap di Departemen Dermatologi dan Venereologi RSUP Sanglah. Jenis-jenis penanganan luka pada defek eksisi tersebut berupa primary intention dengan tindakan flap. Karakteristik pasien dapat dilihat keseluruhan pada Tabel 1.

\section{PEMBAHASAN}

Penelusuran data selama lima tahun didapatkan sebanyak 41 kasus kanker kulit di Departemen Dermatologi dan Venereologi RSUP Sanglah. Pada pasien dengan melanoma (24,4\%), jenis kelamin laki-laki lebih tinggi dibandingkan perempuan dan melanoma terjadi lebih tinggi pada usia lebih dari 50 tahun. Hasil ini sesuai dengan penelitian sebelumnya yang menyatakan bahwa pada 48 pasien yang didiagnosis dengan cutaneous melanoma (CM) lebih tinggi terjadi pada laki-laki (58\%) dibandingkan perempuan (42\%). Usia 5160 didapatkan sebanyak 23\%, 61-70 sebanyak 25\% 
dan usia $>71$ tahun 25\%. ${ }^{7}$ Prognosis yang kurang baik terlihat pada kelompok penduduk Asia dengan acral lentiginous melanoma (ALM). Angka harapan hidup dalam lima dan sepuluh tahun pada pasien dengan ALM primer tanpa metastasis didapatkan masing-masing $80,3 \%$ dan $67,5 \%$ dibandingkan dengan CM masing-masing 91,3 dan 87,5\% pada populasi CM di Amerika Serikat. ${ }^{14}$

Kasus BCC ditemukan 43,9\% yang didominasi pada kelompok laki-laki, usia lebih dari 50 tahun, dan tipe kulit II-IV. Data ini didukung oleh penelitian yang dilakukan di RS Dr. M. Djamil Padang pada tahun 2015-2017 yang didapatkan hasil bahwa kasus BCC ditemukan sebanyak $81 \%(n=31)$ dengan perbandingan laki-laki dan perempuan 1:1 (15:16). ${ }^{9}$ Insiden BCC meningkat hingga 100 kali lipat pada usia lebih dari 50 tahun dibandingkan dengan usia yang lebih muda. ${ }^{3}$ Karsinoma sel basal masih menjadi kanker yang paling sering terjadi di seluruh populasi dan BCC berkontribusi $80 \%$ dari seluruh kanker. ${ }^{1,9}$

Kasus SCC yang ditemukan pada penelitian ini yaitu 21,9\% yang didominasi oleh perempuan, usia lebih dari 50 tahun dan tipe kulit II-IV. Kanker jenis ini ditemukan pada ras kulit hitam dan Asia India masing-masing 30\% dan 65\%. ${ }^{4}$ Penelitian lain juga mendukung bahwa SCC ditemukan sebanyak $16 \%(n=6)$, namun pada penelitian ini lebih tinggi ditemukan pada laki-laki $(n=4)$ dibandingkan dengan perempuan $(n=2) .{ }^{9}$ Walaupun SCC lebih jarang ditemukan dibandingkan BCC, SCC memberikan angka kematian lebih tinggi diakibatkan oleh kasus metastasis yang lebih tinggi. ${ }^{1,4,5}$

Pada keseluruhan kasus didominasi oleh kelompok yang bekerja di luar ruangan dan memiliki kanker pada lokasi wajah. Hal ini sesuai dengan faktor resiko terjadinya kanker kulit oleh karena adanya paparan sinar ultraviolet jangka panjang dan terus menerus tertuma pada wajah yang lebih jarang ditutup saat bekerja di luar ruangan. ${ }^{14,5,9}$ Defek pada wajah akibat eksisi memerlukan penanganan agar mengembalikan fungsi dan kosmetik pada pasien. Pemilihan teknik penutupan defek tersebut sangat menentukan hasil operasi secara kosmetik, terutama mencegah terjadinya distorsi. ${ }^{10,11}$ Pilihan skin flap yang dilakukan pada sampel sebagian besar merupakan simple advancement. Skin flap umumnya dipilih sebagai teknik penutupan defek apabila penutupan primer sederhana tidak dapat dikerjakan karena luka terlampau besar, terdapat banyak regangan pada tepi luka, atau kemungkinan terjadi hasil yang tidak dapat diterima secara fungsional maupun kosmetika. ${ }^{10}$ Walaupun primary closure lebih menguntungkan karena lebih mudah dan meninggalkan bekas luka linier, insisi yang besar pada defek jaringan perlu dilakukan sehingga mengorbankan jaringan normal tidak dapat dihindarkan. Konsep yang prinsip pada rekonstruksi yaitu dimulai dengan metode penutupan paling aman dan minimal invasif, diikuti dengan hasil kosmetik yang baik. Prinsip utama pada rekonstruksi yaitu "fungsi sebelum bentuk, dan bentuk sebelum kosmetika". ${ }^{15}$ Kelemahan dalam penelitian ini adalah tidak adanya faktor resiko lain yang dianalisis karena data yang kurang terintegrasi dan metode penelusuran riwayat yang tidak sama oleh pemeriksa sehingga memungkinkan terjadinya bias informasi. Penelitian lebih lanjut diperlukan untuk dapat mengetahui hasil jangka panjang pada jenis flap yang digunakan pada pasien-pasien dengan kanker kulil dan faktor resiko munculknya kanker kulit di Asia terutama di Indonesia.

\section{SIMPULAN}

Sebanyak 41 pasien dengan kanker kulit terdiri dari BCC 43,9\%; melanoma 24,4\%; SCC $21,9 \%$ dan kanker jenis lain 9,8\%. Faktor resiko pekerjaan diluar ruangan dan usia lebih dari 50 tahun, predileksi kanker pada wajah, flap dengan simple advancement merupakan karakteristik paling umum yang ditemukan pada semua kasus.

\section{DAFTAR PUSTAKA}

1. Qadir MI. Skin cancer: etiologi and management. Pak J Pharm Sci. 2016;29(3):999-1003

2. Apalla Z., Lallas A., Satiriou E., Lazaridou E., Ioannides D. Epidemiological trends in skin cancer. Dermatol Pract Concept. 2017;7(2):1-6

3. Chung S. Basal cell carcinoma. Arch Plast Surg. 2012;39:166-170

4. Silpa SR., Chidvila V. A review on skin cancer. International Research Journal of Pharmacy. 2013;4(8):83-88

5. Yan W., Wistuba II., Emmert-Buck MR., Erickson HS. Squamous cell carcinoma-similiarities and differences among anatomical sites. Am J Cancer Res. 2011;1(3):275300

6. Kim SY., Yun SJ. Cutaneous Melanoma in Asians. Chonnam Med J. 2016;52:185-193

7. Lee HY., Chay WY., Tang MBY., Chio MTW. Melanoma: difference between Asian and Caucasian patients. Ann Acad Med Singapore. 2012;41:17-20

8. Santos VM., Silva RF., Passini VV., Duarte ML., Flores LP. Brain metastasis as initial manifestation of melanoma. Bali Med J. 2016;5(2):295-297

9. Wilvestra S., Lestari S., Asri E. Studi Retrospektif Kanker Kulit di Poliklinik Ilmu Kesehatan Kulit dan Kelamin RS Dr. Djamil Padang Periode Tahun 2015-2017. Jurnal Kesehatan Andalas. 2018;7(Supplement 3):47-49

10. Lee KS., Kim JO., Kim NG., Lee YJ., Park YJ., Kim JS. A comparison of the Local Flap and Skin Graft by Location of Face in Reconstruction after Resection of Facial Skin Cancer. Arch Craniofac Surg. 2017;18(4):255-260

11. Tschoi M., Hoy EA., Granick MS. Skin Flaps. Surg Clin N Am. 2009;89:643-58

12. Patel KG., Sykes JM. Concepts in local flap design and classification. Operative Techniques in Otolaryngology. 2011;22:13-23 
13. Bennet R. Surgical Complication. In: Wolff K, Goldsmith LA, Katz SI, Gilchrest BA, Paller AS, Leffell DJ, editors. Fitzpatrick's Dermatology In General Medicine, $7^{\text {th }}$ ed. USA: McGraw-Hill Company. 2008:2336-41

14. Bellew S., Rosso JQD., Kim GK. Skin cancer in Asians. The Journal of Clinical Aesthetic Dermatology. 2009;2(101):3436

15. Gualdi G., Monari P., Apalla Z., Lallas A. Surgical treatment of basal cell carcinoma and squamous cell carcinoma. G Ital Dermatol Venereol. 2015;150(2):1-14

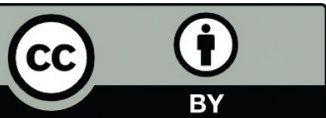

This work is licensed under a Creative Commons Attribution 